\title{
Meta Analisis Komparasi Efektivitas Model Pembelajaran Jigsaw dan Two Stay Two Stray (TSTS) Ditinjau dari Hasil Belajar Pembelajaran Tematik Siswa SD
}

\section{Chintia Wahyuni Puspita Sari ${ }^{1 *}$, Endang Indarini ${ }^{1}$}

\author{
1 Universitas Kristen Satya Wacana, \\ Salatiga, Indonesia, \\ *e-mail: chintiawahyuni094@gmail.com
}

\begin{abstract}
Abstrak
Proses pembelajaran yang masih di dominasi oleh guru yang bersifat konvensional menyebabkan rendahnya hasil belajar tematik siswa SD karena siswa kurang memahami materi dan kurang termotivasi pada saat proses pembelajaran. Penelitian ini bertujuan untuk menguji komparasi efektivitas model pembelajaran Jigsaw dan Two Stay Two Stray untuk meningkatkan hasil belajar siswa SD dari penelitian eksperimen yang dipublikasikan menggunakan metode meta-analisis. Teknik pengumpulan data dengan mencari jurnal yang relevan dengan judul agar lebih mudah untuk mengumpulkan data yang diperlukan. Berdasarkan penelusuran diperoleh 16 jurnal yang sesuai dengan judul penelitian. Teknik analisis data menggunakan metode kuantitatif. Berdasarkan hasil analisis terbukti bahwa model pembelajaran jigsaw dan Two Stay Two Stray (TSTS) dapat meningkatkan hasil belajar pembelajaran tematik siswa SD. Dilihat dari hasil analisis menggunakan uji ancova diperoleh hasil rata-rata nilai Posstest menggunakan model pembelajaran jigsaw sebesar 79,5450 dan peningkatan hasil belajar sebesar 23,59, sedangkan model pembelajaran Two Stay Two Stray (TSTS) mendapatkan hasil skor posttest sebesar 79,5588 dan peningkatan hasil belajar sebesar 28,835. Sedangkan pada uji efek size dilihat dari Partial Eta Squared menunjukkan hasil 0,423 dan nilai signifikasinya yaitu sebesar 0,042 . Dari hasil uji efek size menunjukkan bahwa model pembelajaran Jigsaw dan Two Stay Two Stray (TSTS) berpengaruh sedang terhadap hasil belajar pembelajaran tematik siswa SD.
\end{abstract}

Kata kunci: jigsaw, two stay two stray (tsts), hasil belajar, pembelajaran tematik

\begin{abstract}
The learning process which is still dominated by conventional teachers causes low thematic learning outcomes of elementary school students because students do not understand the material and are motivated to learn during the learning process. This study aims to test the comparative effectiveness of the Jigsaw and Two Stay Two Stray learning models to improve the learning outcomes of elementary school students from published experimental research using the meta-analysis method. Data collection techniques by searching for relevant journals with titles to make it easier to collect the required data. Based on the search, it was obtained 16 journals that match the research title. The data analysis technique used quantitative methods. Based on the results of the analysis it is proven that the jigsaw learning model and Two Stay Two Stray (TSTS) can improve the learning outcomes of elementary students' thematic learning. Judging from the results of the analysis using the Ancova test, it was obtained that the average Posstest score using the jigsaw learning model was 79.5450 and an increase in learning outcomes was 23.59, while the Two Stay Two Stray (TSTS) learning model got a posttest score of 79.5588 and an increase in learning outcomes of 28,835. Meanwhile, the effect size test seen from the Partial Eta Squared shows the result of 0.423 and the significance value is 0.042 . From the results of the effect size test shows that the Jigsaw and Two Stay Two Stray (TSTS) learning model has a moderate effect on the learning outcomes of elementary students' thematic learning.
\end{abstract}

Keywords: jigsaw, two stay two stray (tsts), learning outcomes, thematic learning 


\section{Pendahuluan}

Pembelajaran yang baik adalah pembelajaran yang memberikan kesempatakan kepada peserta didik untuk aktif membangun dan menemukan pengetahuannya sendiri. Peserta didik yang aktif dalam proses pembelajaran akan membuat pembelajaran lebih bermakna. Pembelajaran bermakna akan dihasilkan jika peserta didik mendapatkan pengalaman dan mampu mengembangkan kecerdasan emosi dan proses pembelajaran dilakukan dengan pendekatan kontuktivisme (Angela, 2014; Kostiainen et al., 2018). Pengalaman bisa diperoleh oleh anak melalui kegiatan atau aktivitas pemecahan masalah yang dilakukan dengan proses ilmiah sehingga dihasilkan sebuah bukti dari proses pembelajaran berupa pengalaman yang digunakan dalam kehidupan bermasayarakat (Dewa, 2019). Menghasilkan pembelajaran yang baik tentunya tidak bisa terlepas dari peran guru dalam merancang, melaksanakan pembelajaran dan mengevaluasi pembelajaran. Merancang pembelajaran guru tidak terlepas dari model pembelajaran (Kurnia et al., 2019). Pemilihan model pembelajaran yang sesuai dengan karakteristik dan situasi siswa dapat membuat suasana pembelajaran lebih menyenangkan, menantang dan mampu membuat siswa lebih termotivasi dalam pembelajaran (Irwandani \& Rofiah, 2015). Namun, kenyataannya berbanding terbalik dengan yang diharapakan, saat ini pembelajaran masih menggunkan model pembelajaran konvensional, serta guru masih menggunakan pendekatan teacher center. Penggunaan model pembelajan konvensional akan berdampak terhadap aktifitas dan hasil belajar siswa (Nurdiansyah \& Setuju, 2016). Pembelajaran masih didominasi dengan metode ceramah karena guru merasa belum benar-benar mengajar jika tidak menjelaskan secara panjang lebar (Muliandari, 2019). Proses pembelajaran di dalam kelas diarahkan kepada kemampuan anak untuk menghafal informasi, tanpa dituntun untuk memahami informasi yang diingatnya untuk dihubungkan dengan kehidupan sehari-hari (Kartika et al., 2014). Model pembelajaran sangat diperlukan untuk proses pembelajaran agar siswa termotivasi untuk belajar sehingga hasil belajar tematik siswa SD dapat meningkat. Hasil PISA antara tahun 20002018 juga membuktikan kurang memadainya hasil belajar pendidikan dasar dan menengah. Konsisten sebagai salah satu negara dengan hasil PISA terendah. Mempunyai skor PISA yang stagnan dalam kurun waktu 10 sampai 15 tahun terakhir, namun selisih skor dengan rata-rata skor OECD menunjukkan sedikit peningkatan. Hal ini menjadi perhatian dari Permendikbud (2013). Penjelasan ini dapat dilihat pada grafik 1 berikut.

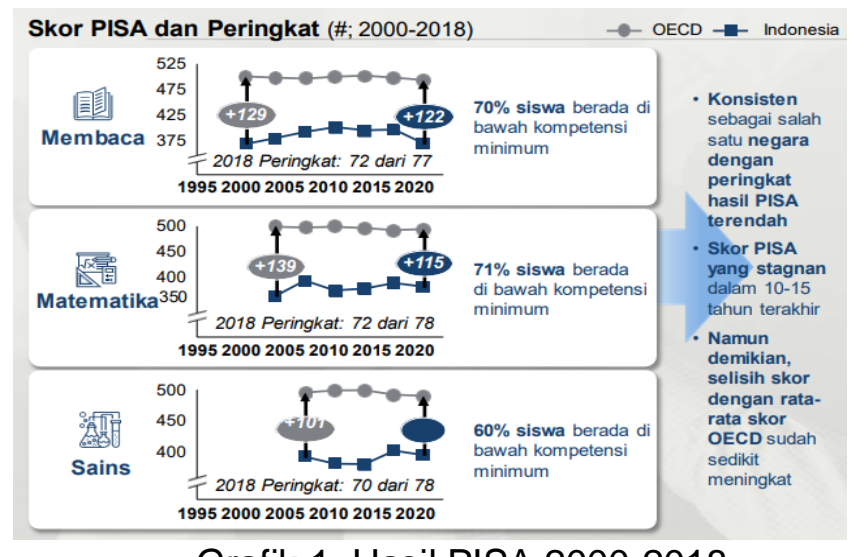

Grafik 1. Hasil PISA 2000-2018

Beberapa solusi pembelajaran sudah dilakukan untuk mengatasi masalah tersebut, salah satunya adalah penerapan model pembelajaran inovatif. Salah satu model inovatif yang digunakan dalam pembelajaran adalah model pembelajaran Jigsaw. Model pembelajaran jigsaw adalah salah satu pembelajaran yang memberikan kesempatan kepada siswa untuk belajar aktif karena model ini berpusat kepada siswa (Maya, 2014). Pembelajaran berpusat kepada siswa akan memberikan kesempatan siswa untuk 
mendapatkan pengalaman lebih banyak yang berpengaruh terhadap hasil belajar siswa. Pembelajaran dengan model jigsaw mampu meningkatkan minat dan aktivitas belajar (Thomas \& Setiaji, 2014), serta pembelajaran dengan model pembelajaran jigsaw dapat meningkatkan hasil belajar siswa (Fadliyani et al., 2018; Kurniawati et al., 2017; Shoffa \& Suprapti, 2017). Hal ini didukung oleh beberapa hasil penelitian. Penelitian yang dilakukan oleh Almukarram et al., (2017) menyatakan bahwa terdapat perbedaan kemampuan berpikir kritis siswa menggunakan penerapan model kooperatif tipe jigsaw dengan pembelajaran konvensional pada konsep pencemaran lingkungan di SMA Negeri 12 Banda Aceh. Alfaris, (2014) menyatakan bahwa ada perbedaan antara kelas yang menggunakan model pembelajaran kooperatif Jigsaw dengan kelas yang menggunakan model pembelajaran konvensional, sebab t hitung 1,466 lebih kecil dari t tabel 2,002. Wati \& Anggraini, (2019) menyatakan bahwa strategi pembelajaran Jigsaw berpengaruh terhadap kemampuan berpikir kritis peserta didik. Marfuah, (2017) menyatakan bahwa penggunaan model pembelajaran kooperatif tipe Jigsaw dapat meningkatkan keterampilan komunikasi peserta didik. Jadi, model pembelajaran jigsaw dapat membuat siswa belajar aktif untuk membangun pengetahunnya sendiri secara mandiri maupaun bekerja bersama dengan teman sebayanya dalam satu kelompok. Selain model pembelajaran Jigsaw salah satu model pembelajaran yang digunakan adalah Two stay two stray.

Two stay two stray (TSTS) memberi kesempatan yang lebih banyak pada siswa untuk bertanya, menjawab, dan saling membantu atau berinteraksi dengan teman (Diarsa et al., 2019; Hendrawan et al., 2017). Two Stay Two Stray dapat melatih peserta didik untuk dapat berinteraksi secara aktif dengan peserta didik yang lain (Darmawan \& Harjono, 2020). Model pembelajaran TSTS, peserta didik juga akan terlibat secara aktif, sehingga akan memunculkan semangat peserta didik dalam belajar (aktif) (Nopridayanti, 2018; Sofian, 2017). Pembelajaran TSTS menekankan pada proses interaksi antara siswa dan teman sebaya dan juga guru. Dengan membentuk interaksi yang baik akan mempu membuat siswa belajar lebih nyaman hal ini tentunya akan berdampak terhadap proses pembelajaran. selain itu pembelajaran dengan model ini akan membuat siswa mendapatkan pengalaman lebih banyak yang berdampak terhadap peningkatan hasil belajar siswa. Penerapan pembelajaran kooperatif tipe TSTS efektif dalam meningkatkan hasil belajar siswa (Hamdi et al., 2014; Zairmi et al., 2019). Hal ini sesuai dengan hasil penelitian yang dilakukan oleh Nurhusain, (2017) menyatakan bahwa hasil belajar matematika siswa yang mengikuti pembelajaran TSTS lebih tinggi dibandingkan siswa yang mengikuti pembelajaran langsung. Mesah et al., (2015) Menyatakan bahwa model Cooperative learning two stay two stray dapat meningkatkan hasil belajar dan keaktifan siswa. Sari et al., (2014) menyatakan bahwa terdapat pengaruh model pembelajaran kooperatif teknik Two Stay Two Stray (TSTS) terhadap hasil belajar biologi siswa. Sunbanu et al., (2019) menyatakan bahwa menunjukann bahwa penelitian ini berhasil meningkatkan keterampilan siswa dalam berkolaborasi menggunakan model pembelajaran Kooperatif Two Stay Two Stray. Jadi, pembelajaran TSTS berdampak positif terhadap proses pembelajaran.

Dua model tersebut harusnya bisa menjadi solusi yang baik terhadap hasil belajar namun, masih banyak guru belum menggunakan model tersebut. Oleh sebab itulah mengapa dibutuhkan sebuah kajian lebih mendalam mengkaji tentang efektivitas kedua model tersebut. Oleh sebab itu akan dilakukan sebuah kajian yang bertujuan untuk melihat apakah terdapat perbedaan efektivitas penggunaan model pembelajaran Jigsaw dan Two Stay Two Stray (TSTS) terhadap hasil belajar pembelajaran tematik pada siswa SD. Beberapa penelitian meta analisis yang pernah dilakukan sudah mengarah pada hasil belajar dan model pembelajaran. Namun belum ada penelitian meta analisis yang membahas tentang model pembelajaran kooperatif pada pembelajaran tematik khususnya pada hasil belajar tematik. Dengan adanya penelitian ini akan memberikan gambaran seberapa efektif penggunaan model pembelajaran Jigsaw dan Two Stay Two Stray (TSTS) terhadap hasil belajar. 


\section{Metode}

Jenis penelitian yang digunakan dalam penelitian ini yaitu penelitian metaanalisis. Meta-analisis yaitu suatu metode penelitian yang di dalamnya berisi analisis dan kombinasi hasi-hasil penelitian sejenis serta mengujinya untuk generalisasi (Punaji 214: 51). Bisa dilihat dari prosesnya, meta-analisis adalah suatu studi yang bersifat observasional retrospektif, didalam penelitiannya seorang peneliti membuat rekapitulasi data akan tetapi tanpa melakukan manipulasi eksperimental. Dimana dimensi effect size yang digabungkan didalam meta-analisis harus sama dengan yang akan dilaporkan didalam artikel yang akan digabungkan. Meta-analisis merupakan sebuah penelitian dengan cara mereview data, lalu merangkum, serta menganlisis hasil dari data sebuah penelitian yang sudah ada sebelumnya. Langkah-langkah penelitian meta analisis yang pertama yaitu merumuskan permasalahan yang akan diteliti. Yang kedua mengumpulkan bahan literatur sesuai dengan judul yang akan diteliti. Yang ke tiga melakukan evaluasi terhadap penelitian yang bertujuan untuk mendapatkan informasi. Yang ke empat melaksanakan Analisa dan membaca literatur yang sudah dicari. Dan yang ke lima menyajikan hasil meta analisis dalam bentuk laporan.

Teknik analisis data penelitian meta-analisis yaitu dengan mencari di pustaka jurnal online dan google scholar sebagai sumber data yang akan dianalisis. Setelah mengumpulkan literatur kemudian dianalisis datu per satu untuk mendapatkan hasil yang diinginkan. Dari hasil pencarian peneliti menemukan 16 jurnal eksperimen dengan kata kunci efektifitas model pembelajaran Jigsaw dan Two Stay Two Stray (TSTS) terhadap hasil belajar pembelajaran tematik siswa SD. Kemudian dari jurnal tersebut di analisis untuk melihat nilai pretest dan posstest yang akan digunakan untuk mengukur hasil belajar siswa sebelum dan sesudah diberikan Tindakan. Setelah didapatkan hasil pretest dan posstest kemudian data tersebut diolah menggunakan SPSS untuk melihat hasil uji efek size. Sebelum melakukan uji efek size dilakukan uji normalitas, uji homogenitas, uji linearitas, dan uji ancova.

\section{Hasil dan Pembahasan}

Berdasarkan hasil penelitian dari beberapa sampel yang sudah ada maka dapat dilihat perbedaan skor pretest dan posstest pada model pembelajaran Jigsaw dan Two Stay Two Stray (TSTS) sebagai berikut:

Tabel 1. Peningkatan Hasil Belajar Pembelajaran Tematik menggunakan model pembelajaran Jigsaw

\begin{tabular}{cccc}
\hline Kode & Pretest & Postest & Peningkatan \\
\hline J01 & 46 & 83 & 37 \\
J02 & 63,20 & 76,40 & 13,20 \\
J03 & 60 & 82 & 22 \\
J04 & 49,09 & 80,05 & 30,96 \\
J05 & 60 & 75 & 15 \\
J06 & 46,07 & 67,10 & 21,03 \\
J07 & 46,97 & 89,81 & 42,84 \\
J08 & 76,3 & 83 & 6,7 \\
\hline Rata-rata & $\mathbf{5 5 , 9 5}$ & $\mathbf{7 9 , 5 4}$ & $\mathbf{2 3 , 5 9}$ \\
\hline
\end{tabular}

Berdasarkan tabel diatas, dapat dilihat bahwa model pembelajaran Jigsaw dapat meningkatkan hasil belajar pembelajaran tematik siswa SD. Rata-rata peningkatan hasil belajar pembelajaran tematik dengan menggunakan model pembelajaran Jigsaw dapat dilihat dari skor terendah sebesar 6,7 serta skor tertinggi sebesar 42,84 dengan jumlah rata-rata sebesar 23,59 . Rata-rata skor pretest hasil belajar pembelajaran tematik dengan menggunakan model pembelajaran Jigsaw yaitu sebesar 55,95. Sedangkan rata-rata skor postest hasil belajar pembelajaran tematik dengan menggunakan model pembelajaran 
Jigsaw yaitu sebesar 79,54. Rata-rata pretest dan postest menggunakan model pembelajaran Jigsaw mengalami peningkatan hasil belajar sebesar 23,59.

Tabel 2. Peningkatan Hasil Belajar Pembelajaran Tematik menggunakan model pembelajaran Two Stay Two Stray (TSTS)

\begin{tabular}{lccc}
\hline Kode & Pretest & Postest & Peningkatan \\
\hline TSTS1 & 50,75 & 90,50 & 39,75 \\
TSTS2 & 41,9 & 84,5 & 42,6 \\
TSTS3 & 48,69 & 73,76 & 25,07 \\
TSTS4 & 46,67 & 67,54 & 20,87 \\
TSTS5 & 40,05 & 69,75 & 29,7 \\
TSTS6 & 69,36 & 84,03 & 14,67 \\
TSTS7 & 45,64 & 87,75 & 42,11 \\
TSTS8 & 62,5 & 78,4 & 15,9 \\
\hline Rata-rata & $\mathbf{5 0 , 6 9 5}$ & $\mathbf{7 9 , 5 5}$ & $\mathbf{2 8 , 8 3 5}$ \\
\hline
\end{tabular}

Berdasarkan tabel diatas, dapat dilihat bahwa model pembelajaran Two Stay Two Stray (TSTS) dapat meningkatkan hasil belajar pembelajaran tematik siswa SD. Rata-rata peningkatan hasil belajar pembelajaran tematik dengan menggunakan model pembelajaran Two Stay Two Stray (TSTS) dapat dilihat dari skor terendah sebesar 14,67 serta skor tertinggi sebesar 42,11 dengan jumlah rata-rata sebesar 28,835. Rata-rata skor pretest hasil belajar pembelajaran tematik dengan menggunakan model pembelajaran Two Stay Two Stray (TSTS) yaitu sebesar 50,695. Sedangkan rata-rata skor postest hasil belajar pembelajaran tematik dengan menggunakan model pembelajaran Two Stay Two Stray (TSTS) yaitu sebesar 79,55. Rata-rata pretest dan postest menggunakan model pembelajaran Two Stay Two Stray (TSTS) mengalami peningkatan hasil belajar sebesar 28,835 .

Tabel 3. Komparasi Pengukuran Hasil Belajar Pembelajaran Tematik

\begin{tabular}{cccc}
\hline Pengukuran & Jigsaw & TSTS & Selisih \\
\hline Pretest & 55,95 & 50,695 & 5,255 \\
Postest & 79,54 & 79,55 & 0,01 \\
\hline
\end{tabular}

Berdasarkan hasil pengukuran komparasi rata-rata skor pada tabel diatas, terdapat rata-rata skor pretest model pembelajaran Jigsaw dengan Two Stay Two Stray yang memiliki selisih 5,255. Sedangkan rata-rata skor posstest antara model pembelajaran Jigsaw dengan Two Stay Two Stray memiliki selisih 0,01.

Tabel 4 Hasil analisis menggunakan uji ancova sebagai berikut:

\begin{tabular}{lccr}
\hline \multicolumn{4}{c}{ Descriptive Statistics } \\
\hline Dependent Variable: & postest & & \\
model_pembelajaran & Mean & Std. Deviation & N \\
\hline model jigsaw & 79.5450 & 6.77129 & 8 \\
model TSTS & 79.5588 & 8.50914 & 8 \\
\hline Total & $\mathbf{7 9 . 5 3 6 9}$ & $\mathbf{7 . 4 2 8 7 4}$ & $\mathbf{1 6}$ \\
\hline
\end{tabular}

Berdasarkan hasil analisis data dengan uji Ancova pada model pembelajaran Jigsaw sebanyak 8 artikel dengan rata-rata 79,5450. Sedangkan model pembelajaran Two Stay Two Stray (TSTS) sebanyak 8 artikel dengan rata-rata 79,5588. Sehingga terdapat perbedaan antara model pembelajaran Jigsaw dan Two Stay Two Stray (TSTS) ditinjau dari peningkatan hasil belajar pembelajaran tematik siswa SD. Pada model pembelajaran Two Stay Two Stray (TSTS) lebih tinggi dibandingkan model pembelajaran Jigsaw dalam peningkatan hasil belajar pembelajaran tematik. 
Tabel 6. Hasil Uji Ancova

\begin{tabular}{|c|c|c|c|c|c|c|}
\hline \multicolumn{7}{|c|}{ Dependent Variable: Posttest } \\
\hline Source & $\begin{array}{l}\text { Type III } \\
\text { Sum of } \\
\text { Squares }\end{array}$ & Df & $\begin{array}{l}\text { Mean } \\
\text { Square }\end{array}$ & $\mathbf{F}$ & Sig. & $\begin{array}{c}\text { Partial } \\
\text { Eta } \\
\text { Squared }\end{array}$ \\
\hline d Model & $456,682^{\mathrm{a}}$ & 1 & 456,682 & 11,339 & 042 & ,423 \\
\hline Interc & 127660,705 & 1 & 127660,705 & 3169,599 &, 000 & ,994 \\
\hline Model_Pembelajaran & 456,681 & 1 & 456,681 & 11,339 & 042 & ,423 \\
\hline Error & 724,979 & 14 & 42,277 & & & \\
\hline Total & 128842,365 & 16 & & & & \\
\hline Corrected Total & 1181,660 & 15 & & & & \\
\hline
\end{tabular}

a. R Squared $=, 386$ (Adjusted R Squared $=, 352$ )

Berdasarkan hasil uji Ancova yang ada pada kolom model pembelajaran bisa disimpulkan bahwa signifikasi pada kolom Sig. yaitu sebesar 0,042. Dimana F hitung yang diperolah yaitu 11,339 serta $F$ tabel yang ada dari data diatas yaitu 3,81. 3,81 diperoleh menggunakan rumus df2 $=\mathrm{n}-\mathrm{k}, \mathrm{df} 2=16-(2+1), \mathrm{df} 2=16-3, \mathrm{df} 2=13$. Untuk bisa menemukan hasil 3,81 dari $F$ tabel yang disesuaikan berdasarkan jumlah sampel lalu dikurang dengan jumlah variabel (bebas dan terikat), jadi bisa ditemukan hasilnya adalah 3,81.

\begin{tabular}{|c|c|c|c|c|c|c|}
\hline \multicolumn{7}{|c|}{ Dependent Variable: Posttest } \\
\hline Source & $\begin{array}{l}\text { Type III } \\
\text { Sum of } \\
\text { Squares }\end{array}$ & Df & $\begin{array}{l}\text { Mean } \\
\text { Square }\end{array}$ & $\mathbf{F}$ & Sig. & $\begin{array}{l}\text { Partial } \\
\text { Eta } \\
\text { Squared }\end{array}$ \\
\hline Corrected Model & $456,682^{a}$ & 1 & 456,682 & 11,339 & ,042 & ,423 \\
\hline Intercept & 127660,705 & 1 & 127660,705 & 3169,599 & 000 & ,994 \\
\hline Model_Pembelajaran & 456,681 & 1 & 456,681 & 11,339 & ,042 & ,423 \\
\hline Error & 724,979 & 14 & 42,277 & & & \\
\hline Total & 128842,365 & 16 & & & & \\
\hline Corrected Total & 1181,660 & 15 & & & & \\
\hline
\end{tabular}

a. $R$ Squared $=, 386$ (Adjusted R Squared $=, 352)$

Penelitian ini dilakukan untuk melihat apakah terdapat perbedaan hasil belajar pada pembelajaran tematik dengan menggunakan model Jigsaw dari beberapa penelitian eksperimen yang sudah di publikasi apakah lebih efektif dari Two Stay Two Stray (TSTS) sesuai dengan rumusan masalah pada penelitian ini dengan menggunakan metode meta analisis. Berdasarkan hasil analisis data dengan uji Ancova pada model pembelajaran Jigsaw sebanyak 8 artikel dengan rata-rata 79,5450. Sedangkan model pembelajaran Two Stay Two Stray (TSTS) sebanyak 8 artikel dengan rata-rata 79,5588. Sehingga terdapat perbedaan antara model pembelajaran Jigsaw dan Two Stay Two Stray (TSTS) ditinjau dari penin gkatan hasil belajar pembelajaran tematik siswa SD. Pada model pembelajaran Two Stay Two Stray (TSTS) lebih tinggi dibandingkan model pembelajaran Jigsaw dalam peningkatan hasil belajar pembelajaran tematik.

Hasil uji Ancova yang ada pada kolom model pembelajaran bisa disimpulkan bahwa signifikasi pada kolom Sig. yaitu sebesar 0,042. Dimana $F$ hitung yang diperolah yaitu 11,339 serta $F$ tabel yang ada dari data diatas yaitu 3,81. 3,81 diperoleh menggunakan rumus df2 $=n-k, d f 2=16-(2+1), d f 2=16-3, d f 2=13$. Untuk bisa menemukan hasil 3,81 dari $F$ tabel yang disesuaikan berdasarkan jumlah sampel lalu dikurang dengan jumlah variabel (bebas dan terikat), jadi bisa ditemukan hasilnya adalah 3,81. Berdasarkan perhitungan hipotesis menggunakan uji Ancova melalui Univariate yang memperlihatkan nilai signifikasi sebesar 0,042 yang artinya nilai signifikasinya lebih kecil dari 0,05 $(0,042<0,05)$. Dari hasil uji Ancova yang membuktikan bahwa f hitung $>\mathrm{f}$ tabel 
yaitu $11,339>3,81$ serta signifikasinya yaitu $0,042<0,05$ dimana dapat disimpulkan bahwa $\mathrm{H}_{\mathrm{o}}$ ditolak dan $\mathrm{H}_{a}$ diterima. Dari hasil tersebut membuktikan bahwa adanya perbedaan yang signifikan antara model pembelajaran Jigsaw dan Two Stay Two Stray (TSTS) yang ditinjau dari hasil belajar pembelajaran tematik siswa SD. uji Effect Size dengan menggunakan uji Ancova pada model pembelajaran Jigsaw dan Two Stay Two Stray (TSTS). Memperoleh hasil pada kolom Corrected Model dimana Partial Eta Squared sebesar 0,423 dimana nilai Sig. sebesar 0,042. Hasil tersebut menunjukkan bahwa pada model pembelajaran Jigsaw dan Two Stay Two Stray (TSTS) memberi pengaruh sedang terhadap hasil belajar pembelajaran tematik pada siswa SD.

Hasil penelitian menunjukkan beberapa temuan. temuan pertama adalah hasil belajar siswa mengalami peningkatan setelah diterapkan model pembelajaran jigsaw. Model pembelajaran jigsaw memberikan kesempatan kepada siswa untuk belajar lebih aktif dan menggali dan menemukan pengetahuanya sendiri baik secara mandiri maupun berkelompok. Model pembelajaran jigsaw adalah salah satu pembelajaran yang memberikan kesempatan kepada siswa untuk belajar aktif karena model ini berpusat kepada siswa (Maya, 2014). Pembelajaran berpusat kepada siswa akan memberikan kesempatan siswa untuk mendapatkan pengalaman lebih banyak yang berpengaruh terhadap hasil belajar siswa. Pembelajaran dengan model jigsaw mampu meningkatakan minat dan aktivitas belajar (Thomas \& Setiaji, 2014), serta pembelajaran dengan model pembelajaran jigsaw dapat meningkatkan hasil belajar siswa (Fadliyani et al., 2018; Kurniawati et al., 2017; Shoffa \& Suprapti, 2017). Hal ini didukung oleh beberapa hasil penelitian. Penelitian yang dilakukan oleh Almukarram et al., (2017) menyatakan bahwa terdapat perbedaan kemampuan berpikir kritis siswa menggunakan penerapan model kooperatif tipe jigsaw dengan pembelajaran konvensional pada konsep pencemaran lingkungan di SMA Negeri 12 Banda Aceh. Alfaris, (2014) menyatakan bahwa ada perbedaan antara kelas yang menggunakan model pembelajaran kooperatif Jigsaw dengan kelas yang menggunakan model pembelajaran konvensional, sebab t hitung 1,466 lebih kecil dari t tabel 2,002. Wati \& Anggraini, (2019) menyatakan bahwa strategi pembelajaran Jigsaw berpengaruh terhadap kemampuan berpikir kritis peserta didik. Marfuah, (2017) menyatakan bahwa penggunaan model pembelajaran kooperatif tipe Jigsaw dapat meningkatkan keterampilan komunikasi peserta didik. Jadi, model pembelajaran jigsaw dapat membuat siswa belajar aktif untuk membangun pengetahunnya sendiri secara mandiri maupaun bekerja bersama dengan teman sebayanya dalam satu kelompok.

Temuan kedua, adalah hasil belajar siswa mengalami peningkatan setelah diterapkan model pembelajaran Two Stay Two Stray (TSTS). Pembelajaran dengan model Two Stay Two Stray (TSTS) memberikan kesempatan siswa untuk membangun interaksi yang baik dengan teman dan guru. Dengan terbangunnya interaksi yang baik antar teman akan mebuat siswa lebih terbuka dan lebih menikmati pembelajaran. Hubungan yang baik antara teman sebaya akan sangat efektif sebagai strategi untuk menarik minat anak dalam proses pembelajaran. Pembelajaran dengan teman sebaya akan mendorong peserta didik untuk berperan aktif dalam pembelajaran (Oh, 2019). Metode teman sebaya meningkatakan pembelajaran sendiri, peserta didik melalui pengalaman yang merupakan umpan balik dari temannya (Gabriele et al., 2016). Teman sebaya membantu, membimbing dan mendukung sesama teman sebaya sehingga mereka mampu membangun pembelajaran melalui interaksi dan kolaborasi (Andersen \& Watkins, 2018). Pembelajaran yang melibatkan teman sebaya akan mengurangi kecemasan dan setres, dengan dibimbing, dibantu, dan diberikan umpan balik oleh teman sebaya peserta didik akan dapat meningkatkan kepercayaan diri (Han et al., 2015; Stone et al., 2013). Dengan penerapan model pembelajaran TSTS akan membuat hubungan anatar teman lebih terbangun erat. Two stay two stray (TSTS) memberi kesempatan yang lebih banyak pada siswa untuk bertanya, menjawab, dan saling membantu atau berinteraksi dengan teman (Diarsa et al., 2019; Hendrawan et al., 2017). Two Stay Two Stray dapat melatih peserta didik untuk dapat beinteraksi secara aktif dengan peserta 
didik yang lain (Darmawan \& Harjono, 2020). Model pembelajaran TSTS, peserta didik juga akan terlibat secara aktif, sehingga akan memunculkan semangat peserta didik dalam belajar (aktif) (Nopridayanti, 2018; Sofian, 2017).

Pembelajaran TSTS menekankan pada proses interaksi antara siswa dan teman sebaya dan juga guru. Dengan membentuk interaksi yang baik akan mempu membuat siswa belajar lebih nyaman hal ini tentunya akan berdampak terhadap proses pembelajaran. selain itu pembelajaran dengan model ini akan membuat siswa mendapatkan pengalaman lebih banyak yang berdampak terhadap peningkatan hasil belajar siswa. Penerapan pembelajaran kooperatif tipe TSTS efektif dalam meningkatkan hasil belajar siswa (Hamdi et al., 2014; Zairmi et al., 2019). Hal ini sesuai dengan hasil penelitian yang dilakukan oleh Nurhusain, (2017) menyatakan bahwa hasil belajar matematika siswa yang mengikuti pembelajaran TSTS lebih tinggi dibandingkan siswa yang mengikuti pembelajaran langsung. Mesah et al., (2015) Menyatakan bahwa model Cooperative learning two stay two stray dapat meningkatkan hasil belajar dan keaktifan siswa. Sari et al., (2014) menyatakan bahwa terdapat pengaruh model pembelajaran kooperatif teknik Two Stay Two Stray (TSTS) terhadap hasil belajar biologi siswa. Sunbanu et al., (2019) menyatakan bahwa menunjukann bahwa penelitian ini berhasil meningkatkan keterampilan siswa dalam berkolaborasi menggunakan model pembelajaran Kooperatif Two Stay Two Stray. Jadi, pembelajaran TSTS berdampak positif terhadap proses pembelajaran

Hasil analisis penelitian menunjukkan bahwa model pembelajaran jigsaw dan Two Stay Two Stray (TSTS) mempunyai pengaruh terhadap hasil belajar tematik siswa SD. $\mathrm{Hal}$ ini bisa menjadi alternatif bagi guru dan peneliti selanjutnya untuk menggunakan model pembelajaran Jigsaw dan Two Stay Two Stray (TSTS) supaya dalam proses pembelajaran siswa dapat lebih aktif, lebih bisa mengembangkan ide yang mereka punya, siswa dilatih untuk bisa tanggung jawab terhadap apa yang mereka lakukan, dan terjalin proses interaksi yang baik antar satu sama lain. Walaupun kedua model memiliki perbedaan efektivitas namun model pembelajaran Jigsaw dan Two Stay Two Stray (TSTS) memiliki pengaruh terhadap hasil belajar siswa. Hal tersebut bisa dibuktikan dari hasil posstest setelah diberi perlakuan menggunakan kedua model tersebut. Serta bisa mendukung teori tentang Jigsaw dan TSTS (Two Stray Two Stray) di tinjau dari hasil belajar siswa SD dalam penelitian meta analisis.

\section{Simpulan}

Jigsaw dan Two Stay Two Stray (TSTS) memiliki pengaruh terhadap hasil belajar siswa. Namun hasil belajar model pembelajaran Two Stay Two Stray (TSTS) lebih tinggi dibandingkan jigsaw. Hal tersebut bisa dibuktikan dari hasil posstest setelah diberi perlakuan menggunakan model tersebut. Serta penelitian ini bisa mendukung teori tentang Jigsaw dan TSTS (Two Stray Two Stray) di tinjau dari hasil belajar siswa SD dalam penelitian meta analisis.

\section{Daftar Pustaka}

Alfaris, A. (2014). Pengaruh Model Pembelajaran Kooperatif Jigsaw Terhadap Prestasi Belajar Menggambar Bentuk di SMA Negeri 3 Tuban. Jurnal Pendidikan Seni Rupa, 2(3), 117-127. https://ejournal.unesa.ac.id/index.php/va/article/view/9900/9694

Almukarram, Sarong, M. A., \& Apriana, E. (2017). Penerapan Model Pembelajaran Kooperatif Tipe Jigsaw Terhadap Peningkatan Kemampuan Berpikir Kritis pada Konsep Pencemaran Lingkungan di SMA Negeri 12 Banda Aceh. BIOTIK: Jurnal IImiah Biologi Teknologi Dan Kependidikan, 4(1), 8. https://doi.org/10.22373/biotik.v4i1.1066

Angela, T. (2014). Challenges to Meaningful Learning in Social Studies - The Key Competences as an Opportunity to Students' Active Participation. Procedia Social and Behavioral Sciences, 128, 192-197. 
https://doi.org/10.1016/j.sbspro.2014.03.142

Darmawan, W., \& Harjono, N. (2020). Efektivitas Problem Based Learning dan Two Stay Two Stray dalam Pencapaian Hasil Belajar. Jurnal Basicedu, 4(2), 402-411. https://doi.org/10.31004/basicedu.v4i2.364

Dewa, A. P. S. (2019). Penerapan Pembelajaran Kooperatif Tipe Team Assisted Individualization (TAI) untuk Meningkatkan Aktivitas dan Prestasi Belajar IPA Pada Siswa Kelas VI SD Negeri 3 Penatih. Vidya Wertta, 2(2), 192-202. https://ejournal.unhi.ac.id/index.php/vidyawertta/article/download/399/322

Diarsa, I. P., Murda, I. N., \& Dharmayanti, P. A. (2019). Pengaruh Model Pembelajaran Two Stay Two Stray Berbantuan Media Visual Terhadap Hasil Belajar IPA Siswa. $\begin{array}{llll}\text { Jurnal Pedagogi Dan } & 94 .\end{array}$ https://doi.org/10.23887/jp2.v1i2.19333

Fadliyani, F., Muhibbuddin, M., \& Sarong, M. A. (2018). Pembelajaran Kooperatif Tipe Jigsaw Pada Konsep Sistem Pencernaan Makanan Manusia Terhadap Hasil Belajar Siswa SMA Negeri 1 Sakti Kabupaten Pidie. BIOTIK: Jurnal IImiah Biologi Teknologi Dan Kependidikan, 2(1), 17. https://doi.org/10.22373/biotik.v2i1.230

Hamdi, R., Jamal, M. A., \& An'nur, S. (2014). Meningkatkan Hasil Belajar Fisika Dengan Menerapkan Model Pembelajaran Kooperatif Tipe Two Stay Two Stray. Berkala IImiah Pendidikan Fisika, 2(3), 265. https://doi.org/10.20527/bipf.v2i3.890

Hendrawan, K., Pudjawan, K., \& Wibawa, I. M. C. (2017). Pengaruh Model Pembelajaran Kooperatif Tipe Two Stay Two Stray (TSTS) terhadap Hasil Belajar Siswa Kelas III di SD Gugus VIII Kecamatan Buleleng Tahun Pelajaran 2016/2017. Jurnal Mimbar PGSD Universitas Pendidikan Ganesha, 5(2), 1-10. https://ejournal.undiksha.ac.id/index.php/JJPGSD/article/download/11014/7065

Irwandani, \& Rofiah, S. (2015). Pengaruh Model Pembelajaran Generatif Terhadap Pemahaman Konsep Fisika Pokok Bahasan Bunyi Peserta Didik MTs Al-Hikmah Bandar Lampung. Jurnal IImiah Pendidikan Fisika Al-Biruni, 4(2), 165. https://doi.org/10.24042/jpifalbiruni.v4i2.90

Kartika, M. D., Santyasa, W., \& Warpala, W. (2014). Pengaruh Model Pembelajaran Berbasis Masalah Terhadap Pemahaman Konsep Fisika Dan Keterampilan Berpikir Kritis Siswa. E- Journal Program Pascasarjana Universitas Pendidikan Ganesha, 4(1). https://media.neliti.com/media/publications/207142-pengaruhmodel-pembelajaran-berbasis-mas.pdf

Kostiainen, E., Ukskoski, T., Ruohotie-Lyhty, M., Kauppinen, M., Kainulainen, J., \& Mäkinen, T. (2018). Meaningful learning in teacher education. Teaching and Teacher Education, 71, 66-77. https://doi.org/10.1016/j.tate.2017.12.009

Kurnia, V. T., Damayani, A. T., \& Kiswoyo, K. (2019). Keefektifan Model Pembelajaran Number Head Together (NHT) Berbantu Media Puzzle Terhadap Hasil Belajar Matematika. Jurnal IImiah Sekolah Dasar, 3(2), 192. https://doi.org/10.23887/jisd.v3i2.17772

Kurniawati, K. R. A., Budiyono, \& Saputro, D. R. S. (2017). Penerapan Model Pembelajaran Kooperatif Tipe Jigsaw Dan Numbered Heads Together Ditinjau Dari Kecerdasan Interpersonal Siswa Pada Pokok Bahasan Bangun Ruang Sisi Datar. Jurnal Pendidikan Matematika, 11(1). https://doi.org/10.22342/jpm.11.1.3948.15-28

Marfuah, M. (2017). Improving Students' Communications Skills Through Cooperative Learning Models Type Jigsaw. Jurnal Pendidikan IImu Sosial, 26(2), 148. https://doi.org/10.17509/jpis.v26i2.8313 
Maya, K. S. (2014). Pengaruh Metode Kooperatif Jigsaw Terhadap Prestasi Belajar Mata Pelajaran IPS Siswa Kelas III. Premiere Educandum, 4(2), 133-147. http://ejournal.unipma.ac.id/index.php/PE/article/view/313/285

Mesah, D. B., Wahyuni, S., \& Liliek, T. (2015). Penerapan cooperative learning two stay two stray untuk meningkatan hasil belajar dan keaktifan siswa SMA. JINoP (Jurnal Inovasi Pembelajaran), $1(1), \quad$ 227-238. https://doi.org/10.22219/jinop.v1i1.2441

Muliandari, P. T. V. (2019). Pengaruh Model Pembelajaran Kooperatif Tipe NHT ( Numbered Head Together ) Terhadap Hasil Belajar Matematika. International Journal Of Elementari Education, 3(2), 132-140. https://doi.org/http://dx.doi.org/10.23887/ijee.v3i2.18517

Nopridayanti. (2018). Penerapan Pembelajaran Kooperatif Tipe Two Stay Two Stray Untuk Meningkatkan Hasil Belajar Ips Peserta Didik Kelas Iv Sd Negeri 003 Beringin Taluk Kecamatan Kuatan Tengah Kabupaten Kuatan Singingi. JURNAL PAJAR (Pendidikan Dan Pengajaran), 2(5), 761. https://doi.org/10.33578/pjr.v2i5.6125

Nurdiansyah, A., \& Setuju. (2016). Penerapan Model Pembelajaran Kooperatif Tipe Jigsaw. E-Jurnal Mitra Sains, 4(2), 54-61. https://doi.org/http://dx.doi.org/10.30738/jtv.v4i1.373

Nurhusain, M. (2017). Impact Analysis of Cooperative Learning Model Application Type Two Stay Two Stray (Tsts) Toward Learning Outcomes of Mathematics. JPMI (Jurnal Pendidikan Matematika Indonesia), 2(2), 46. https://doi.org/10.26737/jpmi.v2i2.220

Sari, E. N., Nilawarni, R., \& Heryanti, E. (2014). Pengaruh Model Pembelajaran Kooperatif Teknik Two Stay Two Stray (TSTS) terhadap Hasil Belajar Biologi Siswa. Biosfer: Jurnal Pendidikan Biologi, 7(1), 25-29. https://doi.org/https://doi.org/10.21009/biosferjpb.7-1.4

Shoffa, S., \& Suprapti, E. (2017). Peningkatan Hasil Belajar Mahasiswa pada Mata Kuliah Metode Numerik dengan Model Pembelajaran Kooperatif Jigsaw. MUST: Journal of Mathematics Education, Science and Technology, 2(2), 178-188. http://journal.um-surabaya.ac.id/index.php/matematika/article/view/736

Sofian. (2017). Upaya Meningkatkan Prestasi Belajar Pkn Melalui Model Pembelajaran Kooperatif Tipe Two Stay Two Stray pada Siswa Kelas IV SD Negeri 007 Pusaran. JURNAL PAJAR (Pendidikan Dan Pengajaran), 1(2), 264. https://doi.org/10.33578/pjr.v1i2.4597

Sunbanu, H. F., Mawardi, M., \& Wardani, K. W. (2019). Peningkatan Keterampilan Kolaborasi Siswa Menggunakan Model Pembelajaran Kooperatif Two Stay Two Stray Di Sekolah Dasar. Jurnal Basicedu, 3(4), 2037-2041. https://doi.org/10.31004/basicedu.v3i4.260

Thomas, P., \& Setiaji, K. (2014). E-Learning Dengan Pendekatan Kooperatif Tipe Jigsaw Untuk Meningkatkan Aktivitas Dan Hasil Belajar Mahasiswa. Dinamika Pendidikan Unnes, 9(1), 21-40. https://doi.org/10.15294/dp.v9i1.3353

Wati, M., \& Anggraini, W. (2019). Strategi Pembelajaran Kooperatif Tipe Jigsaw: Pengaruhnya Terhadap Kemampuan Berpikir Kritis Siswa. Indonesian Journal of Science and Mathematics Education, 2(1), 98-106. https://doi.org/10.24042/ijsme.v2i1.3976

Zairmi, U., Fitria, Y., \& Amini, R. (2019). Penggunaan Model Pembelajaran Two Stay Two Stray Dalam Pembelajaran IPA di Sekolah Dasar. Jurnal Basicedu, 3(4), 10311037. https://jbasic.org/index.php/basicedu/article/view/221 